Provided for non-commercial research and education use. Not for reproduction, distribution or commercial use.

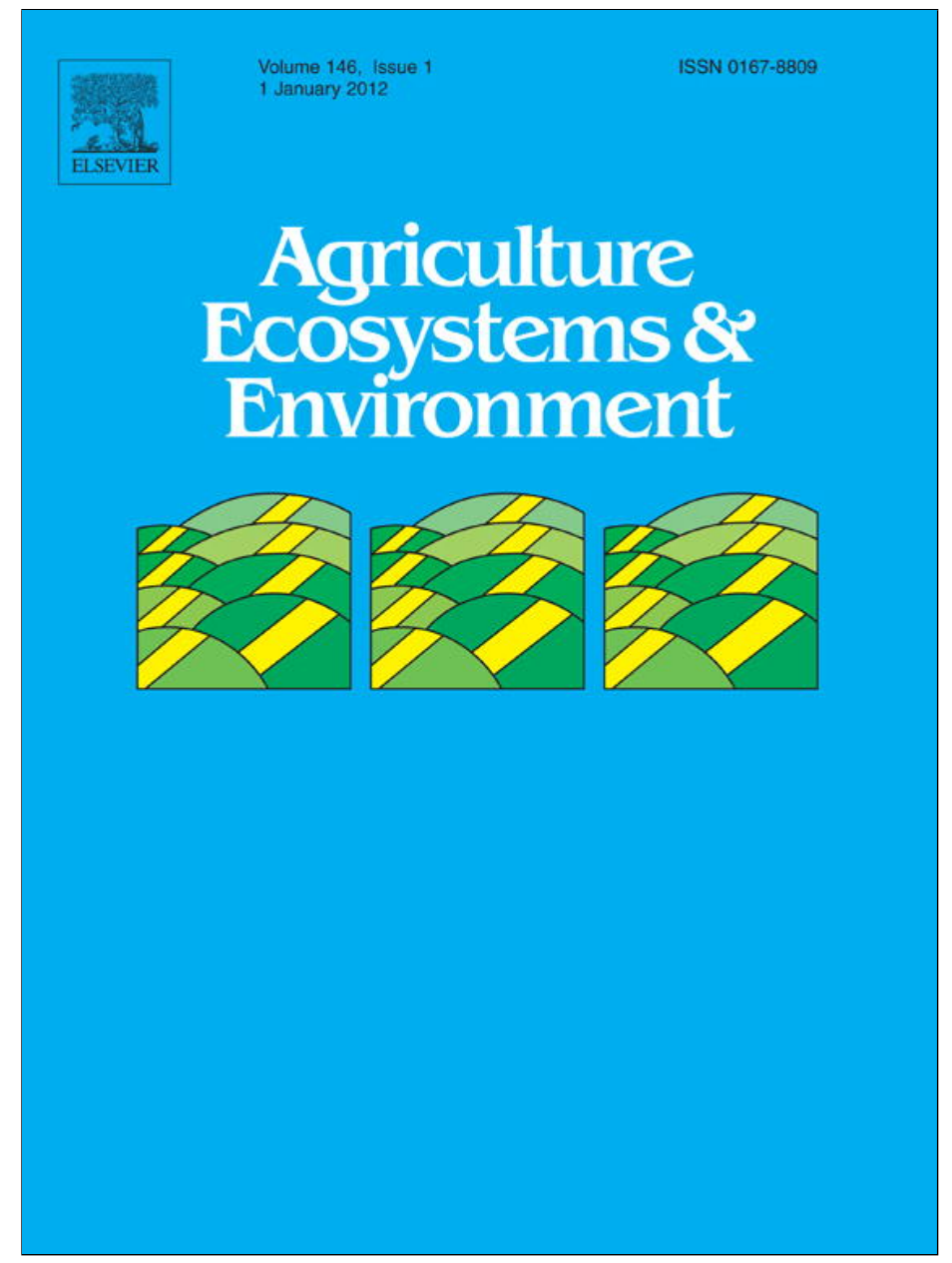

(This is a sample cover image for this issue. The actual cover is not yet available at this time.)

This article appeared in a journal published by Elsevier. The attached copy is furnished to the author for internal non-commercial research and education use, including for instruction at the authors institution and sharing with colleagues.

Other uses, including reproduction and distribution, or selling or licensing copies, or posting to personal, institutional or third party websites are prohibited.

In most cases authors are permitted to post their version of the article (e.g. in Word or Tex form) to their personal website or institutional repository. Authors requiring further information regarding Elsevier's archiving and manuscript policies are encouraged to visit:

http://www.elsevier.com/copyright 


\title{
Assessing and modeling the role of the native legume Lupinus meridanus in fertility restoration in a heterogeneous mountain environment of the tropical Andes
}

\author{
Lina Sarmiento $^{\mathrm{a}, *}$, Josefa Abadín ${ }^{\mathrm{b}}$, Serafín González-Prieto ${ }^{\mathrm{b}}$, Tarsy Carballas ${ }^{\mathrm{b}}$ \\ a Instituto de Ciencias Ambientales y Ecológicas (ICAE), Facultad de Ciencias, Universidad de los Andes, Mérida, Venezuela \\ ${ }^{\mathrm{b}}$ Instituto de Investigaciones Agrobiológicas de Galicia, CSIC, Apartado 122, Avda de Vigo s/n, E-15780, Santiago de Compostela, Spain
}

\section{A R T I C L E I N F O}

\section{Article history:}

Received 2 July 2011

Received in revised form 11 June 2012

Accepted 15 June 2012

\section{Keywords:}

Long fallow agriculture

Nitrogen fixation

Andes

Succession modeling

Environmental heterogeneity

Potato

\begin{abstract}
A B S T R A C T
The role of the native legume Lupinus meridanus on fertility restoration in long fallow agriculture of the Venezuelan Andes was analyzed using field and laboratory data and a process-based model of succession (FAPROM). L. meridanus biomass was estimated in 117 plots with 1-12 years in fallow and $\mathrm{N}_{2}$ fixation was calculated using the natural ${ }^{15} \mathrm{~N}$ abundance. Additionally, the legume was sowed at the beginning of the fallow period in three plots and, after two years, its effect on a posterior potato crop was evaluated. FAPROM was used to simulate $L$. meridanus development and $\mathrm{N}_{2}$ fixation during the fallow period in competition with other five species; after the early introduction of the legume; and in L. meridanus monoculture. High biomass variability between plots of the same age was observed in the field (coefficients of variability exceeding $100 \%$ ). In consequence, the estimated $\mathrm{N}_{2}$ fixation was also variable, increasing during the fallow period to attain a maximum after five years $\left(1.36 \pm 2.84 \mathrm{~g} \mathrm{~N} \mathrm{~m}^{-2} \mathrm{year}^{-1}\right)$ and decreasing afterwards. Cumulative fixation after 10 years in fallow was estimated in $4 \mathrm{~g} \mathrm{~m}^{-2}$, a modest contribution to fertility restoration. Nevertheless, this cumulative value rose to $23.5 \mathrm{~g} \mathrm{~m}^{-2}$ when the potential fixation was estimated considering the plot of each fallow age where L. meridanus attained its highest biomass. FAPROM was modified to include two stochastic sources of variability, in initial soil organic $\mathrm{N}$ and in the probability of colonization of the different species, and succeeded to reproduce mean values and the variability in $L$. meridanus biomass and $\mathrm{N}_{2}$ fixation. Model and experimental data indicate that the early introduction of the legume is a promising strategy to improve potato production and shorten the fallow period. This species has a high potential to fix $\mathrm{N}_{2}$ but its performance is hampered by the low probability of plot colonization.
\end{abstract}

(c) 2012 Elsevier B.V. All rights reserved.

\section{Introduction}

Paramo is the tropical mountain ecosystem found above the timberline $(>3000 \mathrm{~m}$ asl) in the Northern Andes of South America (Ecuador, Colombia and Venezuela). In the central Andes of Peru and Bolivia, under drier conditions, the equivalent ecosystem is the Puna (Monasterio and Vuilleumier, 1986). In both areas, long fallow agriculture is practiced to produce potatoes and cereals (Sarmiento et al., 1993; Hervé et al., 1994). Several functions have been assigned to the fallow period, such as pest and disease control, fertility restoration, provision of areas for grazing and firewood collection, among others. Lupinus meridanus Moritz is the only abundant legume that spontaneously colonizes during the

\footnotetext{
* Corresponding author at: ICAE, Facultad de Ciencias, Universidad de los Andes, Mérida 5101, Venezuela. Tel.: +58 2742401255/2742667030; fax: +58 2742401255. E-mail addresses: lsarmien@ula.ve, linasarmi@gmail.com (L. Sarmiento).
}

fallow periods in the Venezuelan paramo (Sarmiento et al., 2003). $\mathrm{N}_{2}$ fixation by this native species has been suggested as one of the mechanisms of fertility restoration (Abadín et al., 2002; Martineau and Saugier, 2007). The genus Lupinus is well known for its high $\mathrm{N}_{2}$ fixing capacity, due to the symbiotic association with Bradyrhizobium, a $\mathrm{N}_{2}$ fixing microorganism adapted to acidic soils (Dracup et al., 1998; Vielma, 1999). Domesticated species are reported to fix between 13 and $40 \mathrm{~g} \mathrm{~N} \mathrm{~m}^{-2}$ year $^{-1}$ (Howieson et al., 1998). Nevertheless, the potentiality of wild species of lupins has not been fully analyzed and in the case of $L$. meridanus there are not direct quantifications of its $\mathrm{N}_{2}$ fixation efficiency.

A drawback of long fallow agriculture is that only a small proportion of the agricultural land is cultivated at a given time, while most area is maintained in fallow. Strategies for a sustainable intensification are a major concern, but until now intensification in the Venezuelan Andes has been based on the massive use of mineral fertilizers, organic amendments (mainly poultry manure) and agrochemicals, with high environmental costs and low energy 
efficiency. A high dependence on inputs leads to instability and makes the finding of other management alternatives a priority. Furthermore, in a future scenario of global energy shortage, low-input agro-ecological practices, such as the use of legumes for fertility restoration and as green manures, will probably regain its former importance.

Several lupins have been proposed as components of management strategies for systems with low nutrient inputs and for marginal land (Vlek et al., 1981; Biederbeck, 1990). Their use as green manure adds $\mathrm{N}$ to the soil, improving its conservation, reducing water and wind erosion and the use of commercial fertilizers as well (Welty et al., 1988; Andrén et al., 1990; Follet et al., 1991; Hargrove, 1991).

As a tool to understand system functioning, explore management practices, evaluate the current state of knowledge and establish research priorities, a process based model of plant succession (FAPROM: Fallow Production Model), developed by Martineau and Saugier (2007), was used to simulate growth and $\mathrm{N}_{2}$ fixation of $L$. meridanus in competition with other successional species. Stochastic sources of variability were introduced to consider the high spatial heterogeneity that characterizes mountain environments.

The specific aims of this study were: (1) to determine the percentage of L. meridanus $\mathrm{N}$ that is fixed from the atmosphere; (2) to estimate $\mathrm{N}_{2}$ fixation during the fallow period; (3) to test experimentally the possibility of introducing the species at the beginning of the succession as a possible strategy to shorten the fallow period and (4) to explore the potentialities of $L$. meridanus and define priorities for future research using the FAPROM model.

\section{Methodology}

\subsection{The study area and the agricultural system}

The study was carried out in the Paramo of Gavidia, located in the Mérida Andes, Venezuela, between $8^{\circ} 35^{\prime}$ and $8^{\circ} 45^{\prime} \mathrm{N}$ and $70^{\circ} 52^{\prime}$ and $70^{\circ} 57^{\prime} \mathrm{W}$, in the Sierra Nevada National Park. The area consisted of several narrow glacial valleys covered by a mosaic of crop and fallow plots intermingled with natural vegetation. Mean annual temperature, at $3400 \mathrm{~m}$ asl, is $8.4^{\circ} \mathrm{C}$, with a variation of only $2.2{ }^{\circ} \mathrm{C}$ between the coldest and warmest month. Annual rainfall is $1352 \mathrm{~mm}$, with a dry season between November and March. A high environmental heterogeneity characterizes this area, due to the continuous spatial variation in altitude, slope, exposition, topography and land use history. Soils are Inceptisols of 30-60 cm depth, high acidity ( $\mathrm{pH}$ 4.1-5.7) and stoniness, light texture, high organic carbon content (4-12\%) and total N (0.2-0.8\%) (Llambí and Sarmiento, 1998; Abadin et al., 2002). Despite the high soil N content, $\mathrm{N}$ availability is limited since only $2-8 \%$ of this $\mathrm{N}$ is potentially mineralizable (Sarmiento and Bottner, 2002).

In the area, potatoes are cultivated between 3400 and $3800 \mathrm{~m}$ asl using long fallows. The cultivation period lasts for two to three years and the fallow period for five to more than 10 years. Successional plant biomass is incorporated into the soil as green manure at the end of the fallow period and represents an important component of fertility restoration (Sarmiento, 1995).

During the first years of fallow several plant species gradually change their abundance and dominance (Sarmiento et al., 2003). Pioneers, such as the herbs Rumex acetosella and Lachemilla moritziana, are later replaced by other herbs such as Senecio formosus and L. meridanus. After a decade, the shrubs Hypericum laricifolium, Acaena elongata and Baccharis prunifolia dominate, together with the characteristic giant rosette Espeletia schultzii. Despite the existence of clear successional trends, an important heterogeneity in plant composition was observed (Sarmiento et al., 2003).

\subsection{Evaluation of the symbiotic $N_{2}$ fixation by L. meridanus}

The method of natural ${ }^{15} \mathrm{~N}$ abundance for source identification was used, following the recommendations of Shearer and Kohl (1993). A first step was to evaluate if the isotopic composition of the $\mathrm{N}_{2}$ fixed by L. meridanus is significantly different from the soil $\mathrm{N}$ assimilated by non symbiotic species. Shoots and roots of the native legume and of five reference species ( $R$. acetosella, $S$. formosus, L. moritziana, Noticastrum marginatum and A. elongata) collected in the same area, were analyzed for isotopic composition. Total plant $\mathrm{N}$ and $\delta^{15} \mathrm{~N}$ were measured with an elemental analyzer (Carlo Erba CNS 1508) coupled on-line with an isotopic ratio mass spectrometer (Finnigan Mat, delta C, Bremen, Germany).

As a second step, to determine the $\delta^{15} \mathrm{~N}$ in the $\mathrm{N}_{2}$ fixed, plants of $L$. meridanus were cultivated in hydroponic conditions for five months. Five plastic pots were filled with $3.5 \mathrm{~kg}$ of washed gross sand $(1-2 \mathrm{~mm})$ and $840 \mathrm{ml}$ of the Waterer and Vessey's (1993) $\mathrm{N}$-free nutritive solution. Five seeds were sowed in each pot and $250 \mathrm{ml}$ of the nutritive solution were replaced twice a day during 23 weeks. Seven days after sowing, plants were inoculated with Bradyrhizobium extracted from nodules of $L$. meridanus collected in the study area; after 23 weeks, when most of the plants have already dispersed their seeds, above and belowground parts were collected and analyzed for total $\mathrm{N}$ and $\delta^{15} \mathrm{~N}$ as previously described. After subtraction of seed- $\mathrm{N}$, the $\delta^{15} \mathrm{~N}$ of the atmospheric $\mathrm{N}_{2}$ fixed by $L$. meridanus was obtained and the percentage of total $\mathrm{N}$ coming from the atmosphere in plants growing in field conditions was estimated as follows:

$\% \mathrm{Ndfa}=\left[\frac{\delta^{15} \mathrm{~N}_{x}-\delta^{15} \mathrm{~N}_{y}}{\delta^{15} \mathrm{~N}_{x}-\delta^{15} \mathrm{~N}_{c}}\right] 100$

as well as the standard error of this percentage:

$$
\begin{aligned}
\mathrm{SE}_{\% \mathrm{Ndfa}}= & 100\left[\frac{\left(\delta^{15} \mathrm{~N}_{y}-\delta^{15} \mathrm{~N}_{c}\right)^{2}}{\left(\delta^{15} \mathrm{~N}_{x}-\delta^{15} \mathrm{~N}_{c}\right)^{4}}\left(\mathrm{SE}_{x}\right)^{2}+\frac{1}{\left(\delta^{15} \mathrm{~N}_{x}-\delta^{15} \mathrm{~N}_{c}\right)^{2}}\left(\mathrm{SE}_{y}\right)^{2}\right. \\
& \left.+\frac{\left(\delta^{15} \mathrm{~N}_{x}-\delta^{15} \mathrm{~N}_{y}\right)^{2}}{\left(\delta^{15} \mathrm{~N}_{x}-\delta^{15} \mathrm{~N}_{c}\right)^{4}}\left(\mathrm{SE}_{c}\right)^{2}\right]
\end{aligned}
$$

where \% Ndfa is the percentage of the total $\mathrm{N}$ in L. meridanus biomass fixed from the atmosphere, $\delta^{15} \mathrm{~N} x, \delta^{15} \mathrm{~N} y$ and $\delta^{15} \mathrm{~N} c$ are the values of $\delta^{15} \mathrm{~N}$ of reference species $(x)$, of $L$. meridanus in field conditions $(y)$ and growing in N-free hydroponic solution (c) and SE is the standard error.

\subsection{Estimation of $\mathrm{N}_{2}$ fixed during the secondary succession}

The abundance of $L$. meridanus during secondary succession was estimated in 117 plots with 1-12 years of fallow (replications per fallow age, from first to twelfth year in incrementing order: 12,11 , $12,16,17,11,10,9,7,5,4$ and 3 ). Plots were selected using the database of Smith (1995 actualized to 2009), which contains the fallow time of more than 1200 plots in the study area. In each plot, the point intercept method (Greig-Smith, 1983) was used to obtain L. meridanus biovolume. A vertical pin was placed at random at 100 points and the contact with the species at $10 \mathrm{~cm}$ intervals was recorded. The sum of all the contacts between the total points was considered as the biovolume of the species (adimensional). To estimate $L$. meridanus biomass from this non-destructive biovolume measurement, a calibration curve was established. Nine plots of $1 \mathrm{~m}^{2}$, with a large variability in L. meridanus abundance, were chosen, and in each plot the biovolume was measured at plant maturity 


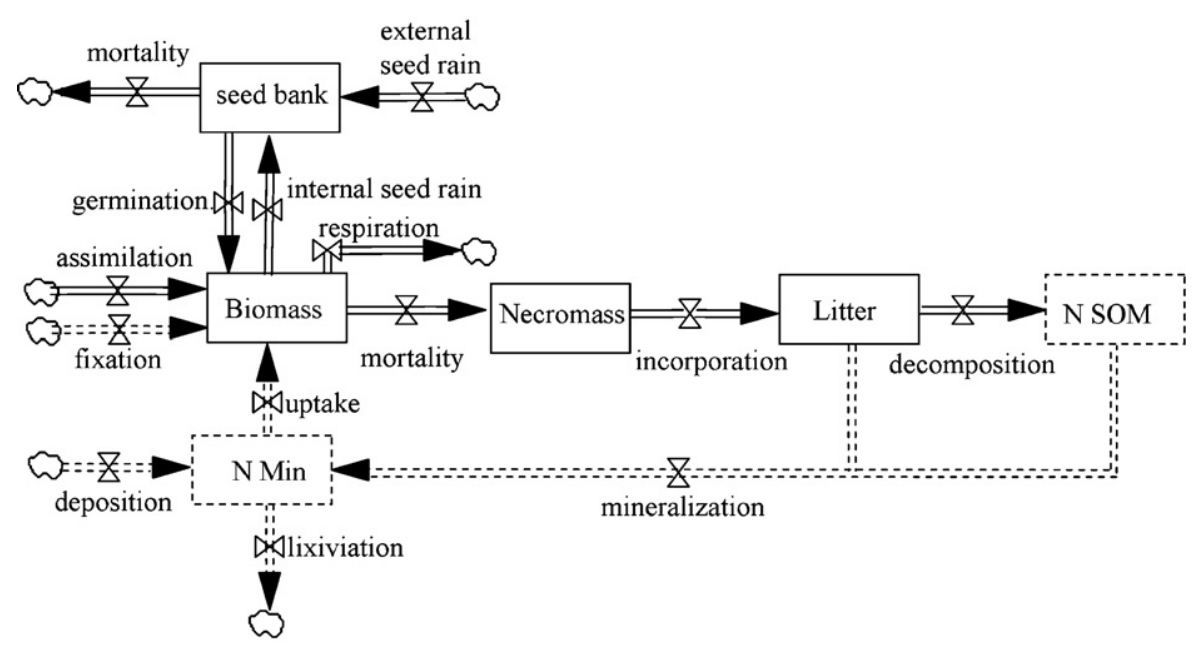

Fig. 1. Simplified structure of the FAPROM model showing the main processes considered to simulate $\mathrm{C}$ and $\mathrm{N}$ cycles. All compartments and fluxes, with the exception of mineral N ( N Min) and soil organic nitrogen (N SOM), are simulated for each species. Dashed lines refer only to $\mathrm{N}$.

Modified from Martineau and Saugier (2007).

using 50 points and above and belowground biomass was collected, oven-dried and weighted.

The pool of $\mathrm{N}$ in the biomass of L. meridanus along the secondary succession was calculated using the mean content of $\mathrm{N}$ in the aboveground biomass and roots obtained in samples of $L$. meridanus collected in the study area. The \% Ndfa was obtained by the same procedure explained above.

\subsection{Improving fallows by early introduction of L. meridanus}

An exploratory three-year experiment was carried out to evaluate the possibility of introducing L. meridanus at the beginning of the succession, to estimate the $\mathrm{N}_{2}$ fixed by the legume and the effect on a posterior potato crop. Three plots of $100 \mathrm{~m}^{2}(10 \mathrm{~m} \times 10 \mathrm{~m})$, that were just harvested and entering into the fallow period, were selected. Each plot was divided in two parts of $50 \mathrm{~m}^{2}$, in one part L. meridanus was sowed at a density of 20 seed $\mathrm{m}^{-2}$, while the other was used as control, allowing the spontaneous colonization of successional species in both parts. L. meridanus was sowed at the beginning of the rainy season using seeds collected in the same locality. After a year, L. meridanus was sowed again in the corresponding treatment. At the end of the second year of fallow, both treatments were prepared for potato cultivation by incorporating all plant biomass into the soil and three months later, at the beginning of the rainy season of the third year, potatoes were planted and fertilized with $30 \mathrm{~g} \mathrm{~m}^{-2}$ of partially acidified rock phosphate and $5 \mathrm{~g} \mathrm{~m}^{-2}$ of potassium as potassium sulfate, without addition of N. Potato density at planting was 4.4 plants $\mathrm{m}^{-2}$.

\subsection{Adaptation, validation and application of the FAPROM model}

A complete description of FAPROM can be found in Martineau and Saugier (2007). The model, developed using the software Vensim (version 5.6b), was conceived to simulate the development of several species during secondary succession in the long fallow agricultural systems of the Venezuelan and Bolivian Andes. FAPROM considers the vegetation as a multilayer mixture of species in competition for light and $\mathrm{N}$. The model predicts biomass production of each species, and takes into account $\mathrm{C}$ and $\mathrm{N}$ fluxes through plants and soil (Fig. 1). It uses a daily time-step, with meteorological data (radiation and rain) as forcing variables. Originally, six species were considered, with four organs: leaves, stems, seeds and roots. It simulates photosynthesis, growth and maintenance respiration, $\mathrm{C}$ allocation, $\mathrm{N}$ uptake, fixation and remobilization and tissue mortality. Seed dispersion and germination are simulated to occur once a year. A simple soil $\mathrm{N}$ model is included that considers litter decomposition, formation and decomposition of soil organic $\mathrm{N}$, mineralization and lixiviation. The soil contains an initial seed bank at the beginning of the fallow period and receives an annual seed rain from inside the plot and from other plots. Competition for $\mathrm{N}$ reduces potential plant assimilation. For each species, $\mathrm{N}$ uptake is determined by $\mathrm{N}$ demand and soil $\mathrm{N}$ availability. If $\mathrm{N}$ availability exceeds $\mathrm{N}$ demand, assimilation proceeds at its potential rate, but if $\mathrm{N}$ demand is higher than $\mathrm{N}$ availability, $\mathrm{C}$ assimilation of each species is reduced according to the $\mathrm{N}$ available to this species. Nitrogen availability is computed as the product of soil mineral $\mathrm{N}$ by the relative root length of the species. When available $\mathrm{N}$ is insufficient to satisfy $L$. meridanus requirements this species fixes the remaining $\mathrm{N}$ from the atmosphere assuming a carbon cost of $4.5 \mathrm{~g}$ $\mathrm{C}$ respired per $\mathrm{g} \mathrm{N} \mathrm{C}$ fixed. FAPROM was partially calibrated and validated by Martineau and Saugier (2007) using information from our study area and considering the six dominant species during the fallow period: $R$. acetosella, L. meridanus, A. elongata, E. schultzii, $H$. laricifolium and B. prunifolia that together represent more than $80 \%$ of the successional plant biomass. The required parameters for each species include photosynthetic constants, $\mathrm{N}$ content by organ, allocation and mortality rates, root specific length, leaf mass area, initial seed bank, annual seed rain, light extinction coefficient, among others (values can be found in Martineau and Saugier, 2007).

The original FAPROM model was slightly modified and some parameters recalibrated to fulfil our requirements. Some of these modifications involve an improved consideration of species phenology. For $R$. acetosella, the main pioneer species, characterized by an extensive root system, a mechanism was implemented to allow translocation of part of root $\mathrm{N}$ to the leaves at the beginning of the growing season. For $L$. meridanus the model was modified to consider the annual life cycle of this species.

The model was run using daily climatic data from the study area collected with a Campbell automatic weather station.

\subsubsection{Application 1: simulation of spatial variability}

In an attempt to reproduce the spatial heterogeneity that characterizes the study area, two sources of variability were introduced 
in the model, the first in the soil initial organic $\mathrm{N}$ pool and the second in the probability of colonization of $L$. meridanus and the other five species. A random normal function was used to generate variability in soil initial organic $\mathrm{N}$, with mean $600 \mathrm{~g} \mathrm{~m}^{-2}$, standard deviation $150 \mathrm{~g} \mathrm{~m}^{-2}$, minimum 300 and maximum $900 \mathrm{~g} \mathrm{~m}^{-2}$, based on data reported by Llambí and Sarmiento (1998). To include the variability in species colonization, two random factors were incorporated. The first one was the probability of a seed bank to be present at the beginning of the fallow period $\left(P_{\text {seed bank }}\right)$ taken as the proportion of 1 year plots where each species was present:

$P_{\text {seed bank }}=\frac{1 \text { year plots with the species }}{\text { total } 1 \text { year plots }}$

The second was the probability of occurrence of a seed rain from outside the plot $\left(P_{\text {seed rain }}\right)$ that was calculated considering the increment in the species presence between plots of 1 and 2 years in fallow:

$P_{2 \text { year plots }}=\frac{2 \text { year plots with the species }}{\text { total } 2 \text { year plots }}$

$P_{\text {seed rain }}=\frac{P_{2 \text { year plots }}-P_{\text {seed bank }}}{1-P_{\text {seed bank }}}$

Both probabilities (Table 1 ) were derived from the presence/absence data of each species along the succession according to Sarmiento et al. (2003). In the model, a homogeneous random function between 0 and 1 was used and when the obtained value was less that the probability for each species the event (seed bank or seed rain) took place.

Not only the occurrence of seed banks at the beginning of the fallow period and of yearly seed rains were randomized but also the quantity of seeds involved. Random normal functions with the parameters listed in Table 1 were used to simulate these quantities.

These two sources of variability were considered in five combinations: (1) variability in soil organic N (var Norg); (2) variability in L. meridanus colonization (seed bank and seed rain, var Lm); (3) simultaneous variability in soil organic $\mathrm{N}$ and $L$ meridanus colonization (var Norg-Lm); (4) simultaneous variability in the probability of colonization of the six species (var Sp); and (5) simultaneous variability in soil organic $\mathrm{N}$ and in the probability of colonization of all species (var Norg-Sp). For each combination 100 Monte Carlo simulations were carried out.

\subsubsection{Application 2: simulation of the succession without $L$. meridanus}

To gain a better understanding of the role of $L$. meridanus in fertility restoration a simulation experiment without this species was carried out. 100 Monte Carlo simulations were performed, considering random variability in species colonization and in soil $\mathrm{N}$ (var Norg-Sp).

\subsubsection{Application 3: simulation of L. meridanus in monoculture}

To assess the potential $\mathrm{N}_{2}$ fixation, a monoculture of $L$. meridanus was simulated by considering a large initial seed bank $\left(10 \mathrm{~g} \mathrm{~m}^{-2}\right)$ for this species and no seed bank or seed rain for the other five species. 100 Monte Carlo simulations were carried out considering random variability only in soil organic $\mathrm{N}$ (var Norg).

\subsubsection{Application 4: improving fallow by early introduction of $L$. meridanus}

To evaluate the effect of an early introduction of the legume, and compare to the experimental data, a simulation experiment was carried out introducing $0.5 \mathrm{~g} \mathrm{~m}^{-2}$ of seeds at the beginning of the first and second year of fallow. 100 Monte Carlo simulations were run, with stochastic variation of the initial soil organic $\mathrm{N}$ and of the probability of colonization of all species (var Norg-sp).

\subsection{Index of fertility}

As FAPROM is not coupled with a potato production model, an index of fertility (IF) was calculated and used as a tool for assessing the role of $L$. meridanus in fertility restoration. To calculate this index the $\mathrm{N}$ in the following compartments was considered: plant biomass $\left(\mathrm{N}_{\mathrm{BIO}}\right)$, plant necromass $\left(\mathrm{N}_{\mathrm{NECRO}}\right)$, plant litter $\left(\mathrm{N}_{\text {LITTER }}\right)$, stable soil organic matter $\left(\mathrm{N}_{\mathrm{MOS}}\right.$ STABLE$)$, labile soil organic matter $\left(\mathrm{N}_{\text {MOS LABIL }}\right)$ and mineral pool $\left(\mathrm{N}_{\mathrm{MIN}}\right)$. Based on the differences in lability, a proportion of the $\mathrm{N}$ of each compartment was considered as available to the potato crop:

$$
\begin{aligned}
\mathrm{IF}\left(\mathrm{g} \mathrm{N} \mathrm{m}^{-2}\right)= & 0.8 \mathrm{~N}_{\mathrm{BIO}}+0.5 \mathrm{~N}_{\mathrm{NECRO}}+0.5 \mathrm{~N}_{\text {LITTER }} \\
& +0.001 \mathrm{~N}_{\text {MOS STABLE }}+0.3 \mathrm{~N}_{\text {MOS LABIL }}+0.8 \mathrm{~N}_{\mathrm{MIN}}
\end{aligned}
$$

This index of fertility, expressed in $\mathrm{g} \mathrm{N} \mathrm{m}^{-2}$, was transformed into $\mathrm{Mg} \mathrm{ha}^{-1}$ of potato fresh weight considering a harvest index of 0.9 , a tuber $\mathrm{N}$ concentration of $2.5 \%$ and a water content of $80 \%$.

\subsection{Statistical analysis}

Means of $\mathrm{N}$ content and $\delta^{15} \mathrm{~N}$ between different species were compared using a one way ANOVA and a Tukey post hoc test. To compare simulated and measured values, several statistical tests were computed following the recommendations of Haefner (2005): (1) Lineal regression between observations and predictions, if the model is perfect all the points would fall on the 1:1 line, the regression slope would be 1 and its intercept would be 0 . To test these two values ( slope $=1$, intercept $=0$ ) simultaneously the $F$ statistic was calculated. (2) A paired $t$-test, the model is validated if the null hypothesis is not rejected. (3) The percent root of the mean squared error of predictions (\%RMSEP) and its three components MC: bias error, SC: slope not unity error and RC random error.

\section{Results}

\subsection{Evaluation of the symbiotic $\mathrm{N}_{2}$ fixation}

L. meridanus had a significantly higher concentration of $\mathrm{N}$ (1.5-2.2 times) and a lower natural abundance of ${ }^{15} \mathrm{~N}$ (approx. 2\%o) than the five non symbiotic species used as reference (Table 2 ).

The plants of $L$. meridanus grown in a $\mathrm{N}$-free hydroponic medium fully developed in four of the five replicates; the fifth was discarded because of the small size of the plants and the small amount of $\mathrm{N}_{2}$ fixed. In the four remaining pots, biomass production ranged from 3.95 to $14.72 \mathrm{~g}$ dry matter per pot and the atmospheric $\mathrm{N}_{2}$ fixed ranged between 4.66 and $20.46 \mathrm{mg} \mathrm{N}$ per pot (Table 3 ). As biomass production and $\mathrm{N}_{2}$ fixation were strongly correlated $(r=0.998$; $p=0.002 ; n=4)$, it can be deduced that plant growth in the $\mathrm{N}$-free hydroponic conditions was limited by the amount of atmospheric $\mathrm{N}_{2}$ they can fix. Therefore, it seems that differences in $\mathrm{N}_{2}$ fixation ability and plant growth were due to irregular inoculation efficiency in the experimental pots. Despite the wide differences in total biomass (ratio 3.7:1) and biologically fixed $\mathrm{N}_{2}$ (ratio 4.4:1), the $\delta^{15} \mathrm{~N}$ values found in the aboveground biomass, roots and total biomass fall within very narrow ranges $(0.27,0.53$ and $0.29 \%$, respectively) and the isotopic composition $\left(\delta^{15} \mathrm{~N}\right)$ of the $\mathrm{N}_{2}$ fixed was very similar, with an average value of $-1.02 \%$ and a standard deviation of $0.14 \%$ (Table 3 ) near to the analytical precision.

Regardless of the reference species, the percentage of $\mathrm{N}$ derived from the atmosphere by $L$. meridanus (\% Ndfa, Table 4) remained 
Table 1

Parameters used to simulated the stochastic seed bank and seed rain for the different species in FAPROM.

\begin{tabular}{|c|c|c|c|c|c|c|}
\hline & \multicolumn{6}{|l|}{ Species } \\
\hline & R. acetosella & L. meridanus & E. schultzii & A. elongata & H. laricifolium & B. prunifolia \\
\hline Probability of a seed bank ${ }^{\mathrm{a}}$ & 1.0 & 0.5 & 0.17 & 0.42 & 0.17 & 0.08 \\
\hline Probability of a seed rain ${ }^{a}$ & 1.0 & 0.1 & 0.34 & 0.69 & 0.34 & 0.21 \\
\hline \multicolumn{7}{|l|}{ Size of the seed bank $\left(\mathrm{g} \mathrm{m}^{-2}\right)^{b}$} \\
\hline Mean & 10 & 0.01 & 0.02 & 0.001 & 0.24 & 0.075 \\
\hline SD & 17.7 & 0.025 & 0.019 & 0.002 & 0.28 & 0.11 \\
\hline Min & 0 & 0 & 0 & 0 & 0 & 0 \\
\hline Max & 40 & 0.1 & 0.1 & 0.01 & 1 & 1 \\
\hline \multicolumn{7}{|l|}{ Size of the seed rain $\left(\mathrm{g} \mathrm{m}^{-2}\right)^{b}$} \\
\hline Mean & 10 & 0.01 & 0.124 & 0.001 & 0.24 & 0.064 \\
\hline SD & 17.7 & 0.025 & 0.118 & 0.002 & 0.28 & 0.098 \\
\hline Min & 0 & 0 & 0 & 0 & 0 & 0 \\
\hline Max & 40 & 0.1 & 1 & 0.01 & 1 & 1 \\
\hline
\end{tabular}

a Calculated based on data of Sarmiento et al. (2003).

b Recalibrated from Martineau and Saugier (2007).

\section{Table 2}

Nitrogen content $(\% \mathrm{~N})$ and natural abundance of ${ }^{15} \mathrm{~N}\left(\delta^{15} \mathrm{~N}\right)$ (average \pm standard deviation) in Lupinus meridanus and five reference species of the secondary succession in Paramo of Gavidia. For each variable, different letters show significant differences among species at $p<0.05$.

\begin{tabular}{|c|c|c|c|c|}
\hline \multirow[t]{2}{*}{ Species } & \multicolumn{2}{|l|}{$\% \mathrm{~N}$} & \multicolumn{2}{|l|}{$\delta^{15} \mathrm{~N}(\%)$} \\
\hline & Aboveground biomass & Roots & Aboveground biomass & Roots \\
\hline Lupinus meridanus & $3.37 \pm 0.07^{\mathrm{a}}$ & $1.65 \pm 0.03^{a}$ & $-0.62 \pm 0.10^{a}$ & $-0.74 \pm 0.10^{a}$ \\
\hline Acaena elongata & $1.52 \pm 0.01^{\mathrm{e}}$ & $0.71 \pm 0.01^{\mathrm{f}}$ & $1.57 \pm 0.03^{b}$ & $1.55 \pm 0.13^{d}$ \\
\hline Lachemilla moritziana & $1.68 \pm 0.03^{d}$ & $1.10 \pm 0.01^{\mathrm{d}}$ & $0.99 \pm 0.23^{b}$ & $3.35 \pm 0.04{ }^{\mathrm{e}}$ \\
\hline Noticastrum marginatum & $2.23 \pm 0.06^{b}$ & $1.30 \pm 0.02^{b}$ & $1.26 \pm 0.42^{b}$ & $2.46 \pm 0.11^{\mathrm{f}}$ \\
\hline Rumex acetosella & $1.68 \pm 0.07^{\mathrm{d}}$ & $0.79 \pm 0.01{ }^{\mathrm{e}}$ & $1.57 \pm 0.06^{b}$ & $1.02 \pm 0.10^{c}$ \\
\hline Senecio formosus & $2.07 \pm 0.05^{c}$ & $1.26 \pm 0.01^{\mathrm{c}}$ & $1.28 \pm 0.44^{b}$ & $0.40 \pm 0.21^{b}$ \\
\hline
\end{tabular}

Table 3

Total biomass (g), fixed atmospheric $\mathrm{N}_{2}(\mathrm{mg})$ and natural ${ }^{15} \mathrm{~N}$ abundance $\left(\delta^{15} \mathrm{~N}\right.$, mean $\pm \mathrm{s}$.d.) in nodulated Lupinus meridanus grown in hydroponic conditions free of $\mathrm{N}$. The $\mathrm{N}$ contribution from the seeds was taken into consideration in the calculations.

\begin{tabular}{|c|c|c|c|c|c|}
\hline \multirow[t]{2}{*}{ Pot } & \multirow[t]{2}{*}{ Total biomass ( $\mathrm{g} \mathrm{dw}$ ) } & \multirow[t]{2}{*}{ Fixed N (mg) } & \multicolumn{3}{|l|}{$\delta^{15} \mathrm{~N}(\%)$} \\
\hline & & & Aboveground biomass & Roots & Total \\
\hline 1 & 14.72 & 20.46 & $-1.35 \pm 0.10$ & $-0.29 \pm 0.11$ & $-1.18 \pm 0.11$ \\
\hline 2 & 3.95 & 4.66 & $-1.16 \pm 0.15$ & $0.21 \pm 0.10$ & $-1.08 \pm 0.14$ \\
\hline 3 & 7.19 & 8.65 & $-1.17 \pm 0.12$ & $0.24 \pm 0.13$ & $-0.89 \pm 0.13$ \\
\hline 4 & 6.08 & 7.86 & $-1.08 \pm 0.14$ & $0.06 \pm 0.15$ & $-0.92 \pm 0.15$ \\
\hline
\end{tabular}

Table 4

Percentage of $\mathrm{N}$ derived from atmosphere (\% Ndfa) in Lupinus meridanus grown in field conditions, calculated based on five reference species from the secondary succession. Data are mean \pm standard error.

\begin{tabular}{lc}
\hline Reference species & \% Ndfa in Lupinus meridanus \\
\hline Acaena elongata & $85.11 \pm 0.62$ \\
Lachemilla moritziana & $82.33 \pm 1.10$ \\
Noticastrum marginatum & $83.92 \pm 2.04$ \\
Rumex acetosella & $84.00 \pm 0.65$ \\
Senecio formosus & $82.53 \pm 2.32$ \\
\hline
\end{tabular}

within a narrow range (82.33-85.11\% of the total $\mathrm{N}$ of $L$. meridanus), with a mean of $83.58 \pm 1.15 \%)$.

\subsection{Nitrogen fixation during secondary succession}

A lineal relationship was found between L. meridanus biovolume and aboveground biomass (Fig. 2), which together with an estimated above: below ground ratio of 15 , was used to calculate $L$. meridanus biomass along the succession. The estimated total biomass of this legume increased from an average of $18.4 \pm 27.5 \mathrm{~g} \mathrm{~m}^{-2}$ during the first year of succession to $46.93 \pm 88.15 \mathrm{~g} \mathrm{~m}^{-2}$ after five years (Fig. 3), declining then to attain

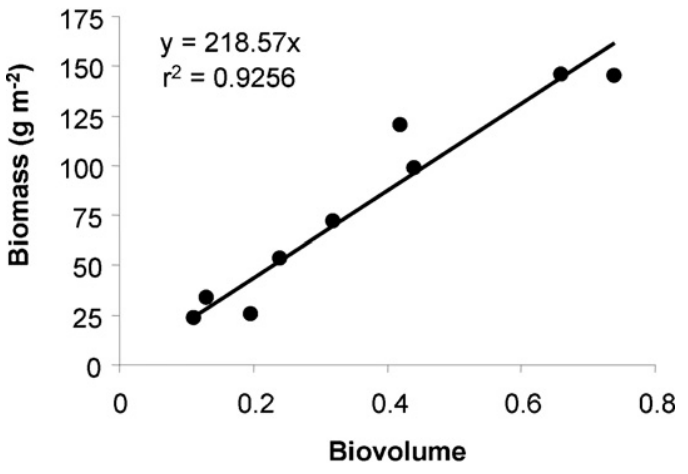

Fig. 2. Linear regression between the non-destructive measure of biovolume and $L$. meridanus aboveground biomass.

its minimum after nine years in fallow $\left(1.25 \pm 3.3 \mathrm{~g} \mathrm{~m}^{-2}\right)$. Based on these data and considering $\mathrm{N}$ concentration of Table 2, an average $\mathrm{N}_{2}$ fixation of $0.53 \pm 0.77 \mathrm{~g} \mathrm{~m}^{-2}$ year $^{-1}$ was obtained for the first year of succession, increasing to $1.36 \pm 2.47 \mathrm{~g} \mathrm{~m}^{-2}$ year $^{-1}$ in five year plots. The cumulative $\mathrm{N}_{2}$ fixation was calculated at $2.76 \mathrm{~g} \mathrm{~m}^{-2}$ and $4.01 \mathrm{~g} \mathrm{~m}^{-2}$ after five and ten years of succession respectively. 

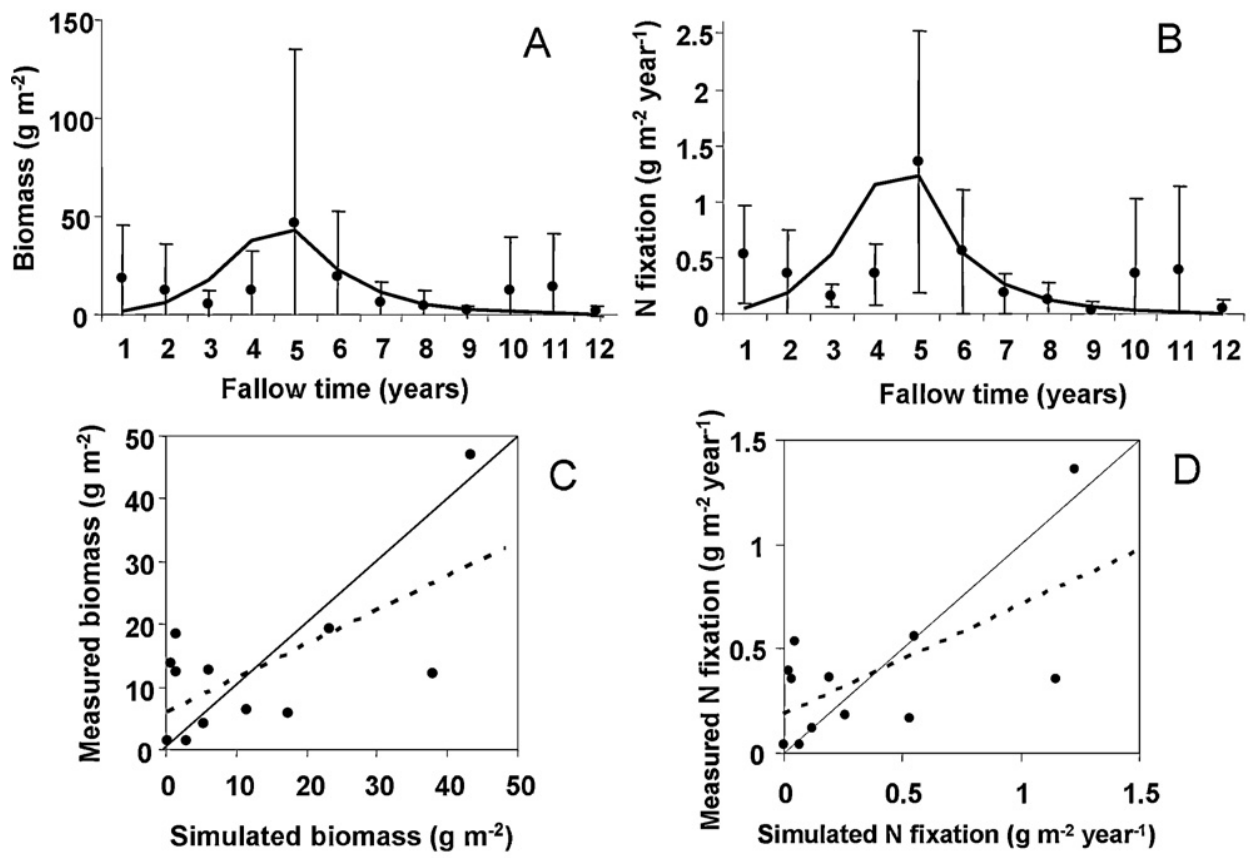

\begin{tabular}{|c|c|c|c|c|c|c|c|c|c|c|}
\hline Simulate & iomass (g r & & & & $\geq \quad$ Simu & Ilated & $\mathrm{N}$ fixation & $m^{-2}$ & $\left(r^{-1}\right)$ & \\
\hline & $\begin{array}{l}\text { Regression } \\
6.00+0.54 x\end{array}$ & $\begin{array}{c}F \\
7.52\end{array}$ & $\begin{array}{c}p \\
0.02\end{array}$ & $\begin{array}{l}\text { Corr } \\
0.66\end{array}$ & $\begin{array}{l}\text { Paired-t } \\
-0.055\end{array}$ & $\begin{array}{c}p \\
0.96\end{array}$ & $\begin{array}{c}\text { \%RMSEP } \\
90\end{array}$ & $\begin{array}{l}\text { MC } \\
0.00\end{array}$ & $\begin{array}{l}S C \\
0.35\end{array}$ & $\begin{array}{l}\mathrm{RC} \\
0.65\end{array}$ \\
\hline $\mathrm{N}$ fixation & $0.19+0.52 x$ & 6.88 & 0.03 & 0.64 & -0.023 & 0.83 & 92 & 0.00 & 0.36 & 0.64 \\
\hline
\end{tabular}

Fig. 3. Results of the standard simulation (without stochastic variability). (A) and (B) are the simulated (line) and observed (solid points, mean \pm standard deviation) $L$. meridanus biomass and $\mathrm{N}_{2}$ fixation during the fallow period. (C) and (D) are the linear regressions between simulated and observed values (dashed lines) and the $1: 1$ line (solid line). A statistical summary of the comparison between observed and simulated data is presented including: linear regression and $F$ statistical to test slope $=1$ and intercept $=0$, correlation coefficient, paired $t$-test, percent of the root of the mean squared error of predictions (\%RMSEP), bias error (MC), slope error (SC) and random error (RC).

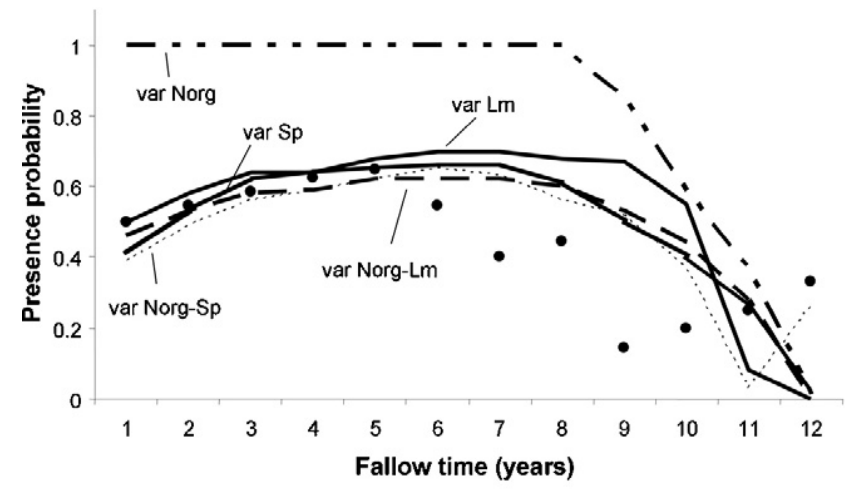

$\begin{array}{lllllllllll} & \text { Regression } & F & p & \text { Corr Paired-t } & \text { p } & \text { \%RMSEP } & \text { MC } & \text { SC } & R C \\ \text { Var Lm } & 0.28+0.28 x & 1.88 & 0.20 & 0.39 & -1.49 & 0.16 & 56 & 0.15 & 0.46 & 0.37 \\ \text { Var Norg } & 0.19+0.31 x & 5.19 & 0.05 & 0.58 & -5.00 & 0.00 & 110 & 0.69 & 0.25 & 0.08 \\ \text { Var Norg-Lm } & 0.22+0.44 x & 2.85 & 0.12 & 0.47 & -1.03 & 0.32 & 44 & 0.08 & 0.30 & 0.62 \\ \text { Var Sp } & 0.19+0.49 x & 4.47 & 0.06 & 0.56 & -1.25 & 0.23 & 43 & 0.12 & 0.30 & 0.58 \\ \text { Var Norg-Sp } & \mathbf{0 . 1 9 + 0 . 5 2 x} & 4.58 & 0.06 & 0.56 & -0.79 & 0.45 & 39 & 0.05 & 0.26 & 0.68\end{array}$

Fig. 4. Probability of $L$. meridanus presence in plots with different fallow time. Solid points are the observed values in 117 plots and lines are the results of 100 Monte Carlo simulations including random variability in: L. meridanus colonization (Var $\mathrm{Lm}$ ), initial soil organic $\mathrm{N}$ (Var Norg), colonization of the six species (Var Sp) and combinations between them. For the statistical summary view explanation in Fig. 3.

A high variability in the estimated $L$. meridanus biomass in plots of the same successional age was obtained. In fact, the species was only present in $50 \%$ of one-year plots and in $65 \%$ of the five-year plots (Fig. 4).

The maximum biomass of $L$. meridanus at each fallow age can be considered as close to the species potential under field conditions. The highest biomass, $366 \mathrm{~g} \mathrm{~m}^{-2}$, was found in a 5-year plot, giving an estimated rate of $\mathrm{N}_{2}$ fixation of $9.9 \mathrm{~g} \mathrm{~N} \mathrm{~m}^{-2}$ year $^{-1}$. Considering the plots with maximum biomass for each successional age a potential cumulated $\mathrm{N}_{2}$ fixation of $23.5 \mathrm{~g} \mathrm{~m}^{-2}$ was estimated for the first ten years of succession.

\subsection{Improving fallow by early introduction of L. meridanus}

L. meridanus succeeded to establish and survive in the three plots where it was sown, despite competition with the highly dominant pioneer species $R$. acetosella. However, plant biomass was much lower in one plot than in the other two (Table 5). Nevertheless, in all the sowed plots, a higher legume biomass was obtained (average of $113.3 \mathrm{~g} \mathrm{~m}^{-2}$ for the first year and $51.6 \mathrm{~g} \mathrm{~m}^{-2}$ for the second) compared to the unmanipulated successional plots where the average was 18.4 and $12.5 \mathrm{~g} \mathrm{~m}^{-2}$ for the first and second year respectively.

In two of the three plots that were cultivated after two years in fallow, potato yield increased with the introduction of $L$. meridanus by factors of 1.8 and 3.2 compared to the control plots, but no difference was detected in the third plot where a lower $L$. meridanus biomass was measured (Table 5).

\subsection{Model validation and applications}

The results of the standard simulation (deterministic model without any source of variability) were compared with field estimates of $L$. meridanus biomass and $\mathrm{N}_{2}$ fixation (Fig. 3). An overall agreement was obtained between the observed mean values and the simulated values with a significant regression between them. The $t$-paired test confirms no significant differences between observed and predicted data and most of the differences between them can be attributed to random effects ( $R C=0.65$ and 0.64 for biomass and $\mathrm{N}_{2}$ fixation respectively). As these results were satisfactory, we proceeded with the different applications of the model. 
Table 5

Above and belowground Lupinus meridanus biomass $\left(\mathrm{g} \mathrm{m}^{-2}\right)$ at the end of the first and second year in the treatment where the legume was introduced (L) and potato yield $\left(\mathrm{Mg} \mathrm{ha}^{-1}\right)$ obtained during the third year in the treatments with (L) and without (C) introduction of L. meridanus.

\begin{tabular}{|c|c|c|c|c|c|c|}
\hline \multirow[t]{3}{*}{ Plot } & \multicolumn{2}{|l|}{ First year } & \multicolumn{2}{|l|}{ Second year } & \multirow{2}{*}{\multicolumn{2}{|c|}{$\frac{\text { Third year }}{\text { Potato yield }}$}} \\
\hline & \multirow[t]{2}{*}{ Aboveground biomass } & \multirow[t]{2}{*}{ Root biomass } & \multirow[t]{2}{*}{ Aboveground biomass } & \multirow[t]{2}{*}{ Root biomass } & & \\
\hline & & & & & $\mathrm{C}$ & $\mathrm{L}$ \\
\hline P1 & 146.0 & 4.6 & 56.8 & 3.8 & 9.2 & 16.6 \\
\hline $\mathrm{P} 2$ & 145.0 & 7.3 & 38.0 & 4.7 & 4.0 & 12.6 \\
\hline P3 & 34.0 & 3.2 & 44.6 & 6.8 & 8.2 & 7.4 \\
\hline
\end{tabular}
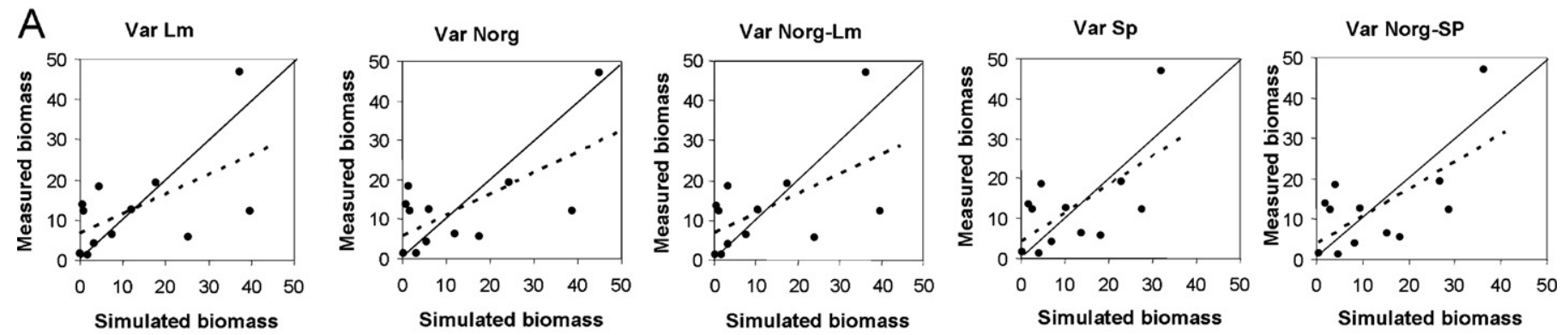

$\begin{array}{lllllllllll} & \text { Regression } & \text { F } & \text { p } & \text { Corr } & \text { Paired-t } & \text { p } & \text { \%RMSEP } & \text { MC } & \text { SC } & \text { RC } \\ \text { Var Lm } & \mathbf{6 . 7 4 + 0 . 4 9 x} & 4.71 & \mathbf{0 . 0 6} & \mathbf{0 . 5 7} & \mathbf{0 . 0 8 1} & \mathbf{0 . 9 4} & \mathbf{9 4} & \mathbf{0 . 0 0} & \mathbf{0 . 3 5} & \mathbf{0 . 6 5} \\ \text { Var Norg } & \mathbf{5 . 9 2 + 0 . 5 3 x} & \mathbf{7 . 7 0} & \mathbf{0 . 0 2} & \mathbf{0 . 6 6} & \mathbf{- 0 . 0 7 9} & \mathbf{0 . 9 4} & \mathbf{9 2} & \mathbf{0 . 0 0} & \mathbf{0 . 3 8} & \mathbf{0 . 6 1} \\ \text { Var Norg-Lm } & \mathbf{6 . 8 9 + 0 . 4 9 x} & \mathbf{4 . 5 0} & \mathbf{0 . 0 6} & \mathbf{0 . 5 6} & \mathbf{0 . 1 6 4} & \mathbf{0 . 8 7} & \mathbf{9 7} & \mathbf{0 . 0 0} & \mathbf{0 . 3 3} & \mathbf{0 . 6 6} \\ \text { Var Sp } & 4.17+0.71 \times & \mathbf{6 . 3 3} & \mathbf{0 . 0 3} & \mathbf{0 . 6 2} & \mathbf{0 . 2 2 1} & \mathbf{0 . 8 3} & \mathbf{7 9} & \mathbf{0 . 0 0} & \mathbf{0 . 0 9} & \mathbf{0 . 9 0} \\ \text { Var Norg-Sp } & \mathbf{4 . 0 9 + 0 . 6 6 x} & \mathbf{7 . 1 0} & \mathbf{0 . 0 2} & \mathbf{0 . 6 4} & \mathbf{- 0 . 1 1 0} & \mathbf{0 . 9 1} & \mathbf{8 0} & \mathbf{0 . 0 0} & \mathbf{0 . 1 5} & \mathbf{0 . 8 5}\end{array}$
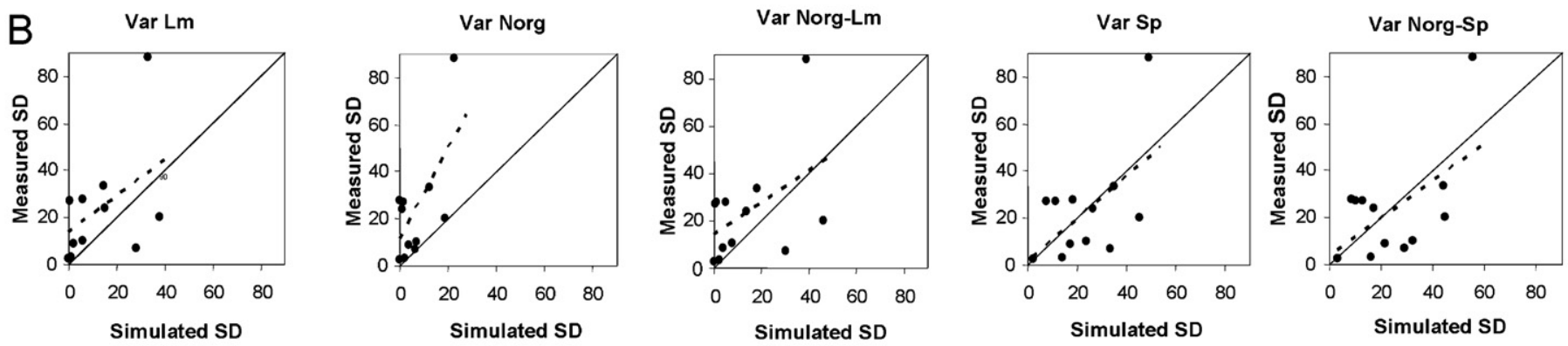

$\begin{array}{lllllllllll} & \text { Regression } & \text { F } & \text { p } & \text { Corr Paired-t } & \text { p } & \text { \%RMSEP } & \text { MC } & \text { SC } & \text { RC } \\ \text { Var Lm } & 13.9+0.77 x & 2.67 & 0.13 & 0.46 & 1.856 & 0.09 & 102 & 0.22 & 0.02 & 0.74 \\ \text { Var Norg } & 10.9+1.94 x & 6.94 & 0.03 & 0.64 & 3.055 & 0.01 & 112 & 0.42 & 0.08 & 0.47 \\ \text { Var Norg-Lm } & 13.9+0.67 x & 2.77 & 0.13 & 0.47 & 1.518 & 0.16 & 100 & 0.16 & 0.05 & 0.78 \\ \text { Var Sp } & 2.04+0.90 x & 4.82 & 0.05 & 0.57 & -0.057 & 0.95 & 81 & 0.00 & 0.01 & 0.99 \\ \text { Var Norg-Sp } & 3.27+0.80 x & 5.14 & 0.05 & 0.58 & -0.254 & 0.89 & 82 & 0.00 & 0.03 & 0.97\end{array}$

Fig. 5. Linear regressions between (A) simulated and observed L. meridanus biomass and (B) simulated and observed standard deviation (SD) of the biomass. The $1: 1$ lines (solid) and regression lines (dashed) are presented. Different sources of variability were considered and a statistical summary (view Fig. 3) of the comparison between observed and predicted data is included.

In the analysis of the spatial heterogeneity (Section 2.5.1), the percentage of plots colonized by $L$. meridanus along the succession was reasonably well simulated by including a randomized factor in species colonization (Fig. 4). The best result was obtained considering random colonization for the six species, together with random variability in soil initial $\mathrm{N}$, with a significant regression between simulated and measured $L$. meridanus presence $(r=0.56)$, the highest probability of accepting Ho (0.45), the lowest \%RMSEP (39) and low bias (0.05) and slope errors (0.26). For the biomass, the best simulation was also obtained when stochastic colonization of all species was included, both for the mean values (Fig. 5A) as for its variability (standard deviation, Fig. 5B). From Figs. 4 and 5, the simulation that included all sources of variability (var Norg-Sp) was selected as the one that best reproduces the spatial heterogeneity in the study area.

Simulated annual $\mathrm{N}_{2}$ fixation obtained in the different applications is shown in Fig. 6 and compared with field estimates when possible. In the unmanipulated succession the simulation produced similar fixation values to the observed means, but the maximum fixation obtained in the 100 Monte Carlo simulations was higher than the maximum observed in the field, with exception of the first and fifth year (Fig. 6A). The simulated maximum was considered as the potential $\mathrm{N}_{2}$ fixation during the succession, around $40 \mathrm{~g} \mathrm{~m}^{-2}$ cumulated after 10 years of unmanipulated succession.

The monoculture simulation produced the highest values of $\mathrm{N}_{2}$ fixation during the succession, starting with $20 \mathrm{~g} \mathrm{~m}^{-2}$ year $^{-1}$ and 


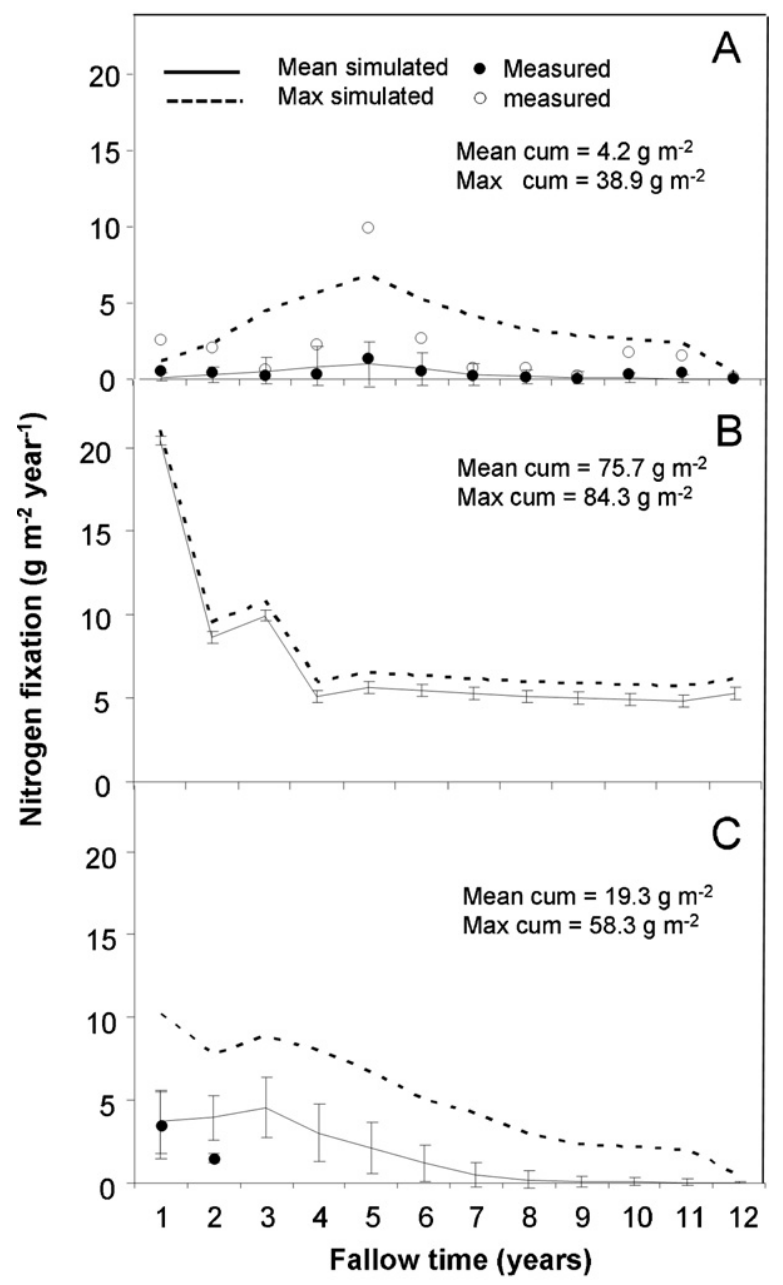

Fig. 6. Mean and maximum $\mathrm{N}_{2}$ fixation obtained in 100 Monte Carlo simulations in three scenarios: (A) unmanipulated secondary succession, (B) L. meridanus monoculture and (C) early introduction. All possible sources of variability were considered in each scenario. Points are the values observed in the field (solid: mean values and hollow: maximum value). Error bars correspond to the standard deviation of the simulated values. Mean and maximum simulated cumulative fixation after 10 years is indicated.

stabilizing around $5 \mathrm{~g} \mathrm{~m}^{-2}$ year ${ }^{-1}$ after four years (Fig. 6B). In this application, the variability (standard deviation in Fig. 6B) was introduced by the randomization of the initial soil $\mathrm{N}$, with higher values of $\mathrm{N}_{2}$ fixation in plots with less initial $\mathrm{N}$.

The early introduction simulation predicted a higher $\mathrm{N}_{2}$ fixation during the first four years and then the values became similar to those of the unmanipulated succession (Fig. 6C). The Monte Carlo simulations showed an important variability between the plots (high standard deviation). Model prediction was in good agreement with the field estimate of $\mathrm{N}_{2}$ fixation in the early introduction experiment for the first year and was overestimated in the second year.

Fertility restoration in the four different applications can be visualized using the fertility index (Fig. 7). In all cases, the index predicted an increase in potato production as plots go through longer fallow periods. The presence of $L$. meridanus in the unmanipulated succession causes an increase in potato production of $4 \%$ after one year and $18 \%$ after six years, compared with the simulation without $L$. meridanus. For the early introduction of $L$. meridanus the model predicted a large increase in potato production, with a percent difference of $49 \%, 76 \%$ and $82 \%$ after the first, second and fifth year respectively. Finally, the monoculture application predicted a spectacular increment in potato production, which increases from

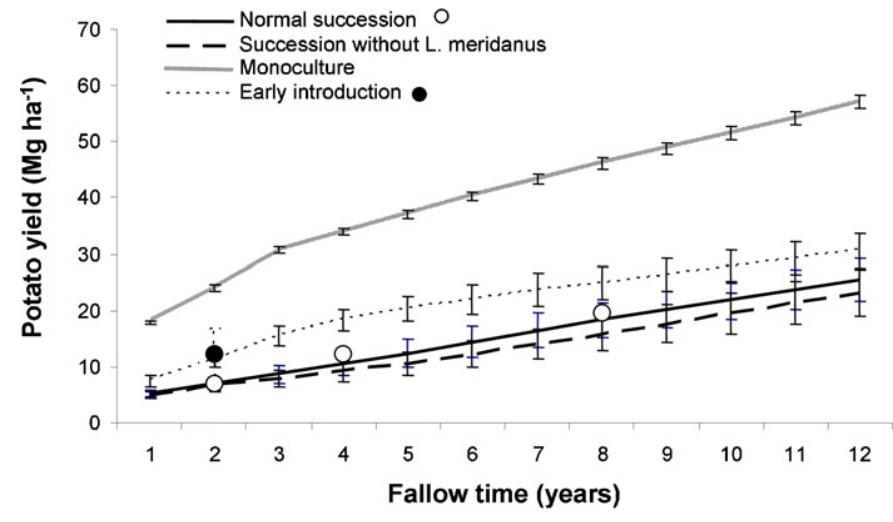

Fig. 7. Simulation of potato yield in plots with different fallow lengths in four scenarios: unmanipulated succession, succession without $L$. meridanus, early introduction of the legume and monoculture. In all cases the results are the mean and standard deviation of 100 Monte Carlo simulations considering stochastic variability in colonization of all species and in initial soil organic $\mathrm{N}$. The validation points come from two sources: after two fallow years from the early introduction experiment and after four and eight years from 23 farmers' plots (Sarmiento, 1995).

$17 \mathrm{Mg} \mathrm{ha}^{-1}$ after one year of monoculture to $57 \mathrm{Mg} \mathrm{ha}^{-1}$ after 12 years. Four validation points were included in Fig. 7, using data from potato production in farmer fields and from the early introduction experiment and a good agreement was found.

\section{Discussion}

\section{1. $N_{2}$ fixation efficiency and potentialities of L. meridanus}

The difference in natural ${ }^{15} \mathrm{~N}$ abundance between the nonlegume reference species and $L$. meridanus ( $2 \%$ ower in the latter) was similar to that mentioned by Gathumbi et al. (2002) in studies with legumes and it was considered, a priori, to be large enough to assess $\mathrm{N}_{2}$ fixation by L. meridanus in the study area using the ${ }^{15} \mathrm{~N}$ natural abundance method. On the other hand, the aboveground biomass isotopic signature of $-1.02 \pm 0.14 \%$, obtained for the fixed $\mathrm{N}_{2}$ from the hydroponic culture of $L$. meridanus, with no other source of $\mathrm{N}$ than the atmospheric, remained below $-1.0 \%$, coinciding with the observations by Okito et al. (2004), and within the range of -2.0 to $0.0 \%$ reported for legumes by Boddey et al. (2000). These negative values are common in the aerial parts of most legumes that are entirely dependent on $\mathrm{N}_{2}$ fixation for growth, indicating the preference for ${ }^{14} \mathrm{~N}$ (Yoneyama et al., 1986; Unkovich et al., 1994). In the roots, the values were slightly positive, coinciding with the reports of Shearer et al. (1984), Yoneyama et al. (1986) and Okito et al. (2004).

The isotopic signature of the legume was compared to those of the species used as reference and, regardless of the species, the \% Ndfa remained within a narrow range, over $80 \%$, which is at the top of the range given by other authors for this genus (Anderson et al., 1998; Howieson et al., 1998; Barrientos et al., 2002), and close to the values obtained by Okito et al. (2004) in various legumes. These values, high and very reproducible, show the large proportional contribution of biologically fixed $\mathrm{N}_{2}$ to the $\mathrm{N}$ nutrition of this species.

The high fixation efficiency of $L$. meridanus, its natural abundance during the succession (it is one of the ten more abundant species according to Sarmiento et al., 2003) and its concentration of $\mathrm{N}$, which is probably the largest among paramo successional plants (Berbesí, 1991; Llambí et al., 2003), position this species as a very promising alternative to improve $\mathrm{N}$ management in paramo agroecosystems. It has a potential use in rotation schemes or improved fallows and has also the advantage of being a native plant, 
resistant to grazing, and adapted to the conditions of the high tropical climate (recurrent frost, high radiation), and acid soils.

\subsection{The role of $L$. meridanus in fertility restoration}

The contribution of biological $\mathrm{N}_{2}$ fixation to a labile $\mathrm{N}$ pool may play an important role in fertility recovery during the fallow periods, considering the low $\mathrm{N}$ availability in paramo soils (Sarmiento and Bottner, 2002). However, the contribution of L. meridanus, at the average plant density found in fallow plots, was estimated at about $4 \mathrm{~g} \mathrm{~m}^{-2}$ after 10 years, a low figure when compared to potato crop requirements $\left(14 \mathrm{~g} \mathrm{~m}^{-2}\right.$ to achieve a yield of $\left.20 \mathrm{Mg} \mathrm{ha}^{-1}\right)$ and that does not explain alone the recovery of fertility during the fallow period. Nevertheless, the contribution of $L$. meridanus to the $\mathrm{N}$ cycle in paramo soils might be higher than these estimations of $\mathrm{N}$ stored in its biomass, since it did not take into account the importance of organic-N rhizodeposition by lupine species (Goergen et al., 2009). Moreover, the abundance of $L$. meridanus in successional fields was highly variable and after five years of succession, when it reaches its peak, $L$. meridanus biomass ranged from 0 in $35 \%$ of the sampled plots, to a maximum of $366 \mathrm{~g} \mathrm{~m}^{-2}$, the latter representing an estimated annual input of atmospheric $\mathrm{N}_{2}$ of about $9.9 \mathrm{~g} \mathrm{~m}^{-2}$, equivalent to $70 \%$ of crop requirements.

Although the amount of $\mathrm{N}$ exuded by roots of $L$. meridanus under field conditions is missing, it could be concluded that the contribution of the legume to the $\mathrm{N}$ balance is modest during secondary succession, except in plots where the species attain higher abundances.

\subsection{Early introduction: strategy to speed up fertility restoration?}

The early introduction experiment indicated that it is possible to manipulate the abundance of $L$. meridanus through its sowing at the beginning of the succession and without any further treatment. In average, $L$. meridanus biomass in the sowed plots was higher that the mean values obtained in the unmanipulated succession, considering plots of any age, suggesting that seed dispersal may be one of the factors limiting the development of $L$. meridanus in successional plots. As most pioneer plants, L. meridanus has high values of photosynthetic rates, leaf $\mathrm{N}$ concentration and specific leaf area that allow a fast growth rate and represent a competitive advantage for space occupation (Llambí et al., 2003). Nevertheless, seed arrival is not the only limitation to L. meridanus establishment, as suggested by one of the three plots where the legume was sowed but developed much lower biomass, indicating that other factors influence plant performance, maybe related to soil or other competitive condition in this plot.

In the two sowed plots where L. meridanus attained a high biomass, potato production increased by factors of 1.8 and 3.2, compared to the unmanipulated succession; a very promising result requiring further confirmation in a larger number of plots. In this regard, Sivila de Cary and Hervé (2006) found similar results comparing potato production in plots with and without a significant biomass of native legumes (Lupinus Otto-buchtienii, Trifolium amabile and Astragalus micranthellus) in fallow systems of the Bolivian Puna, with an increase in potato yield from 9.9 to $20.9 \mathrm{Mg} \mathrm{ha}^{-1}$.

\subsection{Spatial heterogeneity and its influence on system functioning}

Many ecological phenomena are sensitive to spatial heterogeneity and fluxes within spatial mosaics (see for example Kumar et al., 2006). In mountain ranges, this natural heterogeneity is magnified by the confluence of several sources of variability related to the abrupt topography. The high variability in L. meridanus biomass in plots with the same fallow time detected in the study area, can be considered as a manifestation of this spatial heterogeneity, which influences the input of $\mathrm{N}_{2}$ by fixation and consequently the dynamics of soil fertility restoration.

In previous studies in the same area, aimed to establish successional trends using a synchronic approach (substitution of time by space), spatial heterogeneity hampered the detection of clear differences in most of the analyzed variables (Llambí and Sarmiento, 1998; Abadín et al., 2002; Abreu et al., 2009). In this context, average values are meaningless as they do not truly represent the state of the system. This is why successional changes in L. meridanus biomass can hardly be understood by comparing mean values, as the standard deviation is very large and the differences cannot be statistically proven. But, if the presence of the species at a given fallow age is considered as a cumulative probability over time, the picture becomes much clearer. This is why the inclusion in the FAPROM model of random factors in colonization (seed bank and seed rain), not only for $L$. meridanus but for all the simulated species, lead to results reproducing fairly well the real situation.

The structure of the successional landscape (a heterogeneous mosaic of plots in different stages) certainly influences the probabilities of seed dispersion and colonization, depending on the distance to the source and the composition of adjacent plots. In the case of $L$. meridanus, the ability to disperse is hampered by the large size of the seeds of this annual species with no obvious adaptation for dispersion, except for ballistic dispersal when legumes dehisce. However, the low dispersal ability can be compensated by a long persistence in the seed bank. Wood and del Moral (2000) pointed out that, for other species, Lupinus lepidus, found in the primary succession of Mount St Helens, dormancy is enforced by a hard coat and testa preventing water imbibing. The existence of a similar mechanism could explain the presence of $L$. meridanus in $50 \%$ of the one year fallow plots. On the other hand, the low dispersal ability would explain why the probability of occurrence of the species increases very slowly in consecutive years, going only from $50 \%$ to $65 \%$ in the first five years.

Potato production is also highly variable in this mountain landscape, even in plots with the same fallow period, variability that was reproduced by FAPROM when random factors were introduced in species colonization and in the organic soil $\mathrm{N}$ content and when a fertility index was used to transform model results into estimates of potato production.

\subsection{What have we learn from the model?}

FAPROM succeeds to reproduce the mean L. meridanus biomass observed during the succession, indicating that the overall mechanisms and parameters considered are adequate. More interesting is that $\mathrm{N}_{2}$ fixation was well reproduced by the model. The "observed" values of $\mathrm{N}_{2}$ fixation were calculated from $L$. meridanus biomass, taking into account that $83.6 \%$ of its $\mathrm{N}$ comes from the atmosphere. On the other hand, FAPROM considers that the entire $\mathrm{N}$ required by L. meridanus, which is not found in the soil, is fixated from the atmosphere. Despite the different approaches, simulated and observed values are quite similar, indicating that the mechanism used by the model to simulate $\mathrm{N}_{2}$ fixation is close to reality.

The measured variability in L. meridanus biomass in the study area was also quite correctly reproduced by the stochastic version of FAPROM, when random variability in species colonization as well as in the initial values of soil organic $\mathrm{N}$ were included. This represents a good improvement in our previous knowledge on system functioning and provides an adequate platform to analyze the succession in its heterogeneous framework. As variability in species colonization appears to be an important factor determining successional trajectories, its manipulation can be an alternative to improve fertility restoration. Particularly, the early introduction of $L$. meridanus seems a promising strategy to speed up fertility restoration, as was confirmed by the early introduction experiment. 
The monoculture application simulated a potential $\mathrm{N}_{2}$ fixation by $L$. meridanus of $20 \mathrm{~g} \mathrm{~m}^{-2}$, which falls in the range reported by several authors for different domesticated lupins species (Castillo, 1989; Larson et al., 1989; Unkovich et al., 1997; Howieson et al., 1998; Barrientos et al., 1999; Peoples et al., 2001; Urzúa, 2005), but this figure must be validated through further field experimentation. In order to attain its fixation potential, the contribution of $P$ to improve nodule mass and symbiotic $\mathrm{N}_{2}$ fixation has to be considered (Graham and Rosas, 1979; Pereira and Bliss, 1987; Vadez et al., 1999; Olivera et al., 2004; Edwards et al., 2006; Reed et al., 2007).

One of the main goals of simulation models is to identify gaps in the actual knowledge and to define research priorities. In this sense, some of the identified priorities were to assess the spatial variability of the seed bank and seed rain, to check the performance of $L$. meridanus in monoculture and to carry out a more complete validation of the early introduction as a strategy to improve fallow periods.

Finally, both field and simulated results, confirm that L. meridanus can find a place in sustainable agriculture intensification in high tropical environments, either in monoculture as a green manure, or in improved fallows.

\section{Acknowledgments}

This work was framed within the TROPANDES project (Fertility management in the tropical Andes: Sustainable agroecological bases for a fallow agriculture) of the European Union (INCO-DC ERBIC18CT98-0263) and received additional funding from CDCHTA of the Universidad de los Andes (C-1362-05-01-A). The isotopic ratio mass spectrometer was partly financed by the European Regional Development Fund (EU). We especially thank Julia Smith for her support in several phases of the work and in the English revision, Nelson Marquez, Ana Escalona, Auxiliadora Olivo and Zulay Mendez for their assistance in field and laboratory work and Guillermo Sarmiento and Marc Pansu for correcting the manuscript. The Torres family of Páramo de Gavidia, provided constant logistical support, especially Ms. Candida Rosa and her son Bernabé.

\section{References}

Abadín, J., González-Prieto, S.J., Sarmiento, L., Villar, M.C., Carballas, T., 2002. Successional dynamics of soil characteristics in a long fallow agricultural system of the high tropical Andes. Soil Biol. Biochem. 34, 1739-1748.

Abreu, Z., Llambí, L.D., Sarmiento, L., 2009. Sensitivity of soil restoration indicators during paramo succession in the high tropical Andes: chronosequence and permanent plot approaches. Restor. Ecol. 17 (5), 619-628.

Anderson, G., Fillery, I., Dolling, P., Asseng, S., 1998. Nitrogen and water flows under pasture-wheat and lupin-wheat rotations in deep sands in Western Australia. 1 Nitrogen fixation in legumes, net $\mathrm{N}$ mineralisation, and utilisation of soil-derived nitrogen. Aust. J. Agric. Res. 49, 329-343.

Andrén, O., Lindberg, T., Paustian, K., Rosswall, T., 1990. Ecology of Arable LandOrganisms, Carbon and Nitrogen Cycling. Ecol. Bull., vol. 40. Munksgaard International Booksellers and publishers, Copenhagen, Denmark, $222 \mathrm{pp}$.

Barrientos, L., Montenegro, A., Pino I., Rouanet J., Peñaloza, E., 1999. Fijación simbiótica de nitrógeno en Lupinus albus en diferentes sistemas de manejo del suelo en un Ultisol de la IX Región de Chile, in Boletín especial. Asociación Argentina de la Ciencia del Suelo. Jornada Técnica Biología del Suelo en Siembra Directa, INTA, CHILE, Buenos Aires, Argentina, pp. 6-8.

Barrientos, L., Montenegro, A., Pino, I., 2002. Evaluación de la Fijación Simbiótica de Nitrógeno de Lupinus albus y Lupinus angustifolius en un Andisol Vilcun del sur de Chile. Rev. Terra 20, 39-44.

Berbesí, N., 1991. Estrategias de asignación de biomasa y nutrientes, en un gradiente sucesional, en plantas del Páramo Andino. Tesis de pregrado. Licenciatura en Biología, Facultad de Ciencias, Universidad de los Andes, Mérida, Venezuela, $148 \mathrm{pp}$.

Biederbeck, V.O., 1990. Sustainable crop production in the Canadian prairies, in Conservation Tillage. In: Prc. Great Plains Conservation Tillage Symp., Bismarck. Gra Plains Agric. Council, Bull, vol. 131, pp. 291-305.

Boddey, R.M., Peoples, M.B., Palmer, B., Dart, P.J., 2000. Use of the ${ }^{15} \mathrm{~N}$ natural abundance method to quantify biological nitrogen fixation in woody perennials. Nutr. Cycl. Agroecosyst. 57, 235-270.
Castillo, D., 1989. Inoculantes e Inoculación. In: V Seminario de Leguminosas de Grano. Series Carillanca, INIA, Temuco, Chile, vol. 10, pp. 39-53.

Dracup, M., Turner, N.C., Tang, C., Reader, M., Palta, J., 1998. Responses to abiotic stresses. In: Gladstones, J.S., Atkins, C., Hamblin, J. (Eds.), Lupins as Crop Plants: Biology, Production and Utilization. CAB International, Wallingford, UK, pp. 227-262.

Edwards, E.J., McCaffery, S., Evans, J.R., 2006. Phosphorus availability and elevated $\mathrm{CO}_{2}$ affect biological nitrogen fixation and nutrient fluxes in a clover-dominated sward. New Phytol. 169, 157-167.

Follet, R.F., Keeney, D.R., Cruse, R.M., 1991. Managing Nitrogen for Groundwate Quality and Farm Profitability. Soil Science Society of America, Madison, WI, $357 \mathrm{pp}$.

Gathumbi, S.M., Cadisch, G., Giller, K.E., 2002. ${ }^{15} \mathrm{~N}$ natural abundance as a tool for assessing $\mathrm{N}_{2}$-fixation of herbaceous, shrub and tree legumes in improved fallows. Soil Biol. Biochem. 34, 1059-1071.

Goergen, E., Chambers, J.C., Blank, R., 2009. Effects of water and nitrogen availability on nitrogen contribution by the legume, Lupinus argenteus Pursh. Appl. Soil Ecol 42 (3), 200-208.

Graham, P.H., Rosas, J.C., 1979. Phosphorus fertilization and symbiotic nitrogen fixation in common bean. Agron. J. 71, 925-926.

Greig-Smith, P., 1983. Quantitative Plant Ecology. University of California Press, Berkeley, $359 \mathrm{pp}$.

Haefner, J., 2005. Modeling Biological Systems: Principles and Applications. Springer, New York, $475 \mathrm{pp}$

Hargrove, W.L., 1991. Cover crops for clean water. In: Proceedings of an Internationa Conference, West Tennessee Experiment Station, Jackson, TN, Soil and Water Conservation Society, Ankeny, April 9-11, 1991, 198 pp.

Hervé, D., Genin, D., Riviere, G., 1994. Dinámicas del descanso de la tierra en los Andes. IBTA-ORSTOM, La Paz, 356 pp.

Howieson, J.G., Fillery, I.R.P., Logocki, A.B., Sikorski, M.M., Stepkowskym, T., Minchin, F.R., Dilworth, M.J., 1998. Nodulation, nitrogen fixation and nitrogen balance. In: Gladstones, J.S., Atkins, C., Hamblin, J. (Eds.), Lupins as Crop Plants: Biology, Production and Utilization. CAB International, Wallingford, UK, pp. 149-180.

Kumar, S., Stohlgren, T.J., Chong, W., 2006. Spatial heterogeneity influences native and nonnative plant species richness. Ecology 87 (12), 3186-3199.

Larson, K., Cassaman, K., Phillips, D., 1989. Yield, dinitrogen fixation, and aboveground nitrogen balance of irrigated white lupin in a Mediterranean climate. Agron. J. 81, 538-543.

Llambí, L.D., Sarmiento, L., 1998. Biomasa microbiana y otros parámetros edáficos en una sucesión secundaria de los páramos venezolanos. Ecotrópicos 11,1-14.

Llambí, L.D., Fontaine, M., Rada, F., Saugier, B., Sarmiento, L., 2003. Ecophysiology of dominant plant species during secondary succession in a high Andean paramo ecosystem. Arct. Antarct. Alp. Res. 35 (4), 447-453.

Martineau, Y., Saugier, B., 2007. A process-based model of old field succession linking ecosystem and community ecology. Ecol. Model. 204 (3-4), 399-419.

Monasterio, M., Vuilleumier, F., 1986. High tropical mountain biota of the World. In: Vuilleumier, F., Monasterio, M. (Eds.), High Altitude Tropical Biogeography. Oxford University Press, New York, pp. 3-7.

Okito, A., Alves, B.R.J., Urquiaga, S., Boddey, R.M., 2004. Isotopic fractionation during $\mathrm{N}_{2}$ fixation by four tropical legumes. Soil Biol. Biochem. 36, 1179-1190.

Olivera, M., Tejera, N., Iribarne, C., Ocaña, A., Lluch, C., 2004. Growth, nitrogen fixation and ammonium assimilation in common bean (Phaseolus vulgaris): effect of phosphorus. Physiol. Plantarum 121, 498-505

Peoples, M.B., Bowman, A.M., Gault, R.R., Herridge, D.F., McCallum, M.H., McCormick, K.M., Norton, R.M., Rochester, I.J., Scammell, G.J., Schwenke, G.D., 2001. Factors regulating the contributions of fixed nitrogen by pasture and crop legumes to different farming systems of eastern Australia. Plant Soil 228, 29-41.

Pereira, P.A., Bliss, F.A., 1987. Nitrogen fixation and plant growth of common bean (Phaseolus vulgaris L.) at different levels of phosphorus availability. Plant Soil 104, 79-84.

Reed, S.C., Seastedt, T.R., Mann, C.M., Suding, K.N., Townsend, A.R., Cherwin, K.L., 2007. Phosphorus fertilization stimulates nitrogen fixation and increases inorganic nitrogen concentrations in a restored prairie. Appl. Soil Ecol. 36, 238-242.

Sarmiento, L., 1995. Restauration de la fertilité dans un système agricole à jachère longue des hautes Andes du Venezuela. PhD thesis, University of Paris XI, Orsay.

Sarmiento, L., Monasterio, M., Montilla, M., 1993. Ecological bases, sustainability, and current trends in traditional agriculture in the Venezuelan high Andes. Mt. Res. Dev. 13 (2), 167-176.

Sarmiento, L., Bottner, P., 2002. Carbon and nitrogen dynamics in two soils with different fallow times in the high tropical Andes: indications for fertility restoration. Appl. Soil Ecol. 19, 79-88.

Sarmiento, L., Llambí, L.D., Escalona, A., Márquez, J., 2003. Vegetation patterns, regeneration rates and divergence in an old-field succession of the high tropical Andes. Plant Ecol. 166, 63-74.

Shearer, G.B., Bryan, B.A., Kohl, D.H., 1984. Increase of natural ${ }^{15} \mathrm{~N}$ enrichment of soybean nodules with mean nodule mass. Plant Physiol. 76, 743-746.

Shearer, G.B., Kohl, D.H., 1993. Natural abundance of $15 \mathrm{~N}$ : fractional contribution of two sources to a common sink and use of isotope discrimination. In: Knowles, R. Blackburn, T.H. (Eds.), Nitrogen Isotope Techniques. Academic Press, San Diego, pp. 89-125.

Sivila de Cary, R., Hervé, D., 2006. Efecto de leguminosas nativas en terrenos en descanso sobre la microbiota del suelo durante un cultivo de papa (Altiplano central boliviano). Ecología en Bolivia 41, 154-166. 
Smith, J.K., 1995. Die Auswirkungen der Intensivierung des Ackerbaus im Paramo de Gavidia-Landnutzungswandel an der oberen Anbaugrenze in den venezolanischen Anden. Diplomarbeit, Geographisches Institut, Universität Bonn.

Unkovich, M.J., Pate, J.S., Sanford, P., 1997. Nitrogen fixation by annual legumes in Australian Mediterranean agriculture. Aust. J. Agric. Res. 48, 267-293.

Unkovich, M.J., Pate, J.S., Sanford, P., Armstrong, E.L., 1994. Potential precision of the delta ${ }^{15} \mathrm{~N}$ natural abundance method in field estimates of nitrogen fixation by crop and pasture legumes in South-West Australia. Aust. J. Agric. Res. 45, $119-132$.

Urzúa, H., 2005. Beneficios de la Fijación Simbiótica de Nitrógeno en Chile. Cien. Inv. Agric. 32, 133-150

Vadez, V., Lasso, J.H., Beck, D.P., Drevon, J.J., 1999. Variability of $\mathrm{N}_{2}$-fixation in common bean (Phaseolus vulgaris L.) under P deficiency is related to P use efficiency. Euphytica 106, 231-242.

Vielma, A.M., 1999. Caracterización de cepas autóctonas de Bradyrhizobium sp. aisladas de Lupinus spp. Rev. Fac. Agron. 16, 495-508.
Vlek, P.L.G., Fillery, K.R.P., Burford, J.R., 1981. Accession, transformation and loss of nitrogen in soils of the arid region. Plant Soil 58, 133-175.

Waterer, J.G., Vessey, J.K., 1993. Nodulation response of autoregulated or $\mathrm{NH}_{4}$ inhibited pea (Pisum sativum) after transfer to stimulatory (low) concentrations of $\mathrm{NH}_{4}$. Physiol. Plantarum 88, 460-466.

Welty, L.W., Prestbye, L.S., Engel, R.E., Larson, R.A., Lockerman, R., Speilman, R.S., Sims, J.R., Kushnak, G., Dubbs, A.L., Hart, L.I., 1988. Nitrogen contribution of annual legumes to subsequent barley production. Appl. Agric. Res. 3 , 98-104.

Wood, D.M., del Moral, R., 2000. Seed Rain During Early Primary Succession on Mount St. Helens, Washington, vol. 47. Madroño, pp. 1-9.

Yoneyama, T., Fujita, K., Yoshida, T., Matsumoto, T., Kambayashi, I., 1986. Variation in natural abundance of ${ }^{15} \mathrm{~N}$ among plant parts and in ${ }^{15} \mathrm{~N} /{ }^{14} \mathrm{~N}$ fractionation during $\mathrm{N}_{2}$ fixation in the legume rhizobia symbiotic system. Plant Cell Physiol. 27, 791-799. 